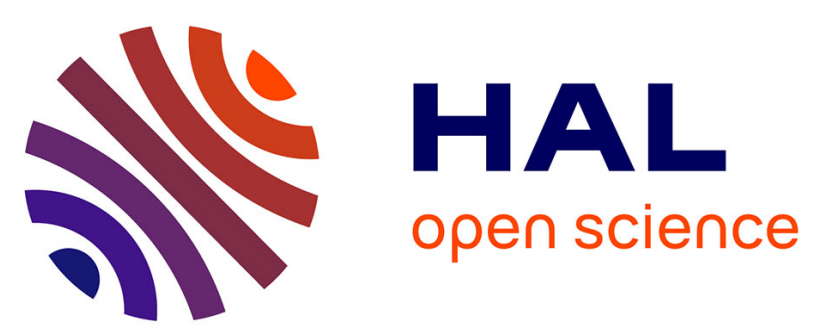

\title{
Efficacy and safety of vinorelbine in heavily pretreated recurrent/metastatic head and neck squamous cell carcinoma patients
}

\author{
Claire Barth, Louise Naveau, Emmanuel Touboul, Sophie Périé, Edith \\ Bamogho, Sophie Haberer-Guillerm, Michel Schlienger, Jean Lacau St Guily, \\ Florence Huguet
}

\section{To cite this version:}

Claire Barth, Louise Naveau, Emmanuel Touboul, Sophie Périé, Edith Bamogho, et al.. Efficacy and safety of vinorelbine in heavily pretreated recurrent/metastatic head and neck squamous cell carcinoma patients. Anti-Cancer Drugs, 2016, 27 (4), pp.349-352. 10.1097/CAD.0000000000000333 . hal-01321391

\section{HAL Id: hal-01321391 \\ https://hal.sorbonne-universite.fr/hal-01321391}

Submitted on 25 May 2016

HAL is a multi-disciplinary open access archive for the deposit and dissemination of scientific research documents, whether they are published or not. The documents may come from teaching and research institutions in France or abroad, or from public or private research centers.
L'archive ouverte pluridisciplinaire HAL, est destinée au dépôt et à la diffusion de documents scientifiques de niveau recherche, publiés ou non, émanant des établissements d'enseignement et de recherche français ou étrangers, des laboratoires publics ou privés. 


\section{EFFICACY AND SAFETY OF VINORELBINE IN HEAVILY PRETREATED}

RECURRENT/METASTATIC HEAD AND NECK SQUAMOUS CELL CARCINOMA PATIENTS

Claire Barth ${ }^{\mathrm{a}}$, Louise Naveau ${ }^{\mathrm{a}}$, Emmanuel Touboul ${ }^{\mathrm{a}}$, Sophie Périé ${ }^{\mathrm{b}}$, Edith Bamogho ${ }^{\mathrm{a}}$, Sophie Haberer-Guillerm ${ }^{\mathrm{a}}$, Michel Schlienger ${ }^{\mathrm{a}}$, Jean Lacau St Guily ${ }^{\mathrm{b}}$, Florence Huguet ${ }^{\mathrm{a}}$.

Departements of ${ }^{a}$ Radiation Oncology and ${ }^{b}$ Head and Neck Surgery, Tenon Hospital, Hôpitaux Universitaires Est Parisien, Faculté de Médecine Pierre et Marie Curie, Université Paris VI, Paris, France.

Corresponding author: Dr Florence HUGUET, Service d'Oncologie Radiothérapie, Hôpital Tenon, 4 rue de la Chine, 75020 Paris, France; tel +33 1560183 22; fax +33 156016400 . florence.huguet@tnn.aphp.fr

Running title: Vinorelbine in head and neck cancer patients. 


\begin{abstract}
The objective of this study was to evaluate the efficacy and tolerance of vinorelbine as a single agent in the treatment of recurrent/metastatic head and neck squamous cell carcinoma. Patients were treated with oral or intra venous vinorelbine according to pluridisciplinary tumor board's decision. Efficacy and safety outcomes were analyzed retrospectively. Twentythree patients were included in the study. Sixteen patients $(69 \%)$ had received at least two previous lines of chemotherapy. The disease control rate was $19 \%$. The median progressionfree survival was 2,6 months and the median overall survival was 3,4 months. The rate of grade 3-4 side effect was low (13\%). Only one patient discontinued treatment because of side effects. Vinorelbine seems to be a well-tolerated regimen in heavily pretreated patients. However, this regimen does not seem to be efficient enough to be recommended.
\end{abstract}

Keywords: head and neck cancer; vinorelbine; recurrent; metastatic; chemotherapy. 


\section{Introduction}

Head and neck squamous cell carcinoma (HNSCC) is one of the leading causes of cancerrelated mortality in the Western world. The GLOBOCAN estimates there has been 513000 new cases in 2012 worldwide. ${ }^{1}$ In France, HNSCC's incidence was of 14638 new cases in 2012 and mortality was of 4098 cases. $^{2}$ After the frontline locoregional treatment based on surgery and chemoradiotherapy, $50 \%$ of patients present a relapse. ${ }^{3}$ In most cases, this relapse is non curable with surgery or radiation therapy. Chemotherapy is then the only therapeutic option used in a palliative intent. Common used drugs are platinum, docetaxel, paclitaxel, 5fluorouracil (5-FU), and methotrexate. The standard first-line treatment for inoperable recurrent or metastatic HNSCC is platinum and 5FU combined with cetuximab. ${ }^{4}$ With this regimen, median overall survival reaches 10 months. The only validated second-line chemotherapy is methotrexate with a poor response rate. ${ }^{5}$ In platinium refractory patients, median overall survival has been estimated to 56 days with best supportive care. ${ }^{6}$ All efforts should be made to improve the prognosis of these patients.

Vinorelbine is a cytostatic drug part of the vinca alkaloid family. Its anti-mitotic activity is caused by inhibition of microtubule polymerization during mitosis. Vinorelbine has been used in lung cancer and breast cancer for many years. ${ }^{7,8}$ It has been previously evaluated as first line in patients with recurrent and/or metastatic HNSCC with a response rate of $16 \%{ }^{9}$ Combined with other drugs, vinorelbine has a modest effect in HNSCC patients. ${ }^{10,11,12}$ It could be interesting to use it as a monotherapy in patients non eligible for conventional treatment because of the comorbidities or numerous previous lines of chemotherapy.

We have retrospectively reviewed efficacy and tolerance of vinorelbine as monotherapy in HNSCC patients with recurrent or metastatic disease pre-treated with at least one line of chemotherapy. 


\section{Patients and methods}

\section{Inclusion criteria}

We included in this study all patients treated with vinorelbine in our institution for a non resectable recurrent or metastatic squamous cell carcinoma of the head and neck between January 2006 and July 2013. Patients were eligible if they were 18 years of age or older and had pathologically confirmed recurrent or metastatic HNSCC. Other inclusion criteria included ineligibility for local therapy. Their medical charts were retrospectively reviewed.

\section{Treatment}

Patients were treated with vinorelbine per os at a dose of $60 \mathrm{mg} / \mathrm{m}^{2}$ on D1, D8 and D15 with D1=D28. If the hematological tolerance was good, the dose was increased to $90 \mathrm{mg} / \mathrm{m}^{2}$ on D1, D8 and D15 after the third cycle of treatment. For patients unable to swallow, vinorelbine was administered IV at a dose of $25 \mathrm{mg} / \mathrm{m}^{2}$ on D1, D8 and D15. Each administration of vinorelbine was preceded by an intake of ondansetron $8 \mathrm{mg}$ half an hour before. Treatment was continued until progression or unacceptable toxicity. Before each new cycle, patients had a physical examination to evaluate tolerance and efficacy of treatment. They had a blood count every week.

Assessment of safety and efficacy

Acute toxicity was evaluated by the clinician and graded at each cycle of chemotherapy according to the Common Terminology Criteria for Adverse Events (CTCAE) version 4.0. Tumor response was assessed by physical examination at every cycle and by computed tomography (CT) or magnetic resonance imaging (MRI) in all patients using RECIST (Response Evaluation Criteria in Solid Tumors) 3 months after the start of vinorelbine and then at 3-month intervals. 


\section{Statistical analysis}

The endpoints assessed were response to chemotherapy, progression free survival (PFS), overall survival (OS), and acute toxicity. The Kaplan-Meier method was used to estimate the PFS and OS. PFS was calculated from the first day of chemotherapy initiation until the date of tumor progression or death. OS was calculated from the first day of chemotherapy initiation until the date of death. Analyses were performed with Statview v5 software.

\section{Results}

\section{Patient characteristics}

From January 2006 through July 2013, 23 patients received vinorelbine for recurrent or metastatic HNSCC at our institution. The initial characteristics of the 23 patients analyzed in this study are reported in Table 1.

The median delay of relapse was 12.3 months (range: 5-103 months), with 13 locoregional recurrences $(57 \%)$, seven metastatic recurrences $(30 \%)$ and three locoregional and metastatic recurrences $(13 \%)$. Patients with metastatic relapse presented mainly with lung metastasis $(70 \%)$.

Two patients $(9 \%)$ received vinorelbine as frontline for the treatment of their relapse, five patients $(22 \%)$ received one line of chemotherapy prior to vinorelbine, 11 patients $(47 \%)$ received two lines of chemotherapy prior to vinorelbine and five patients (22\%) received three lines of chemotherapy prior to vinorelbine. Sixteen patients $(70 \%)$ received cisplatin prior to vinorelbine, 19 patients (83\%) cetuximab, 19 patients (83\%) docetaxel, one (4\%) methotrexate, and one (4\%) gemcitabine plus oxaliplatin (Table 2).

\section{Treatment delivery and safety}


Patients received a mean of 2.2 cycles (range: 1-7). Vinorelbine was mainly administered per os (78\% of patients). Dose reduction was not needed.

All patients were assessable for tolerance. Treatment was stopped prematurely in one patient after two cycles because of grade 3 asthenia.

Acute toxicities are summarized in Table 3. Anemia, diarrhea, and constipation were the most frequent side effects. The overall incidence of severe (grade 3-4) acute toxicity was low with two cases of grade 3 neutropenia (9\%) and one case of grade 3 asthenia (4\%). There was no case of febrile neutropenia. There was no death related to treatment.

\section{Efficacy and survival}

The median follow-up time was 3.4 months (range: 0.1-14.1 months).

Response was assessable in 16 patients. In seven patients, the response was not assessed because they received only one cycle of vinorelbine. No objective tumor response has been observed. Three patients (19\%) had disease stabilization. All of them had a tumor originally located in the oropharynx. Their HPV status was unknown. Among the seven patients who received at least three cycles of vinorelbine, three had tumor stabilization (43\%).

All patients have been included in survival analysis. At the time of analysis, there have been 22 deaths and 23 disease progression. The median PFS was 2.6 months and the median OS was 3.4 months (Figures 1 and 2). The 1-year actuarial PFS and OS rates were $0 \%$ and $4 \%$ (95\% CI, 0-8\%), respectively.

Eight patients have been able to receive another line of chemotherapy after vinorelbine: three patients received methotrexate, two carboplatine, two cetuximab, and one capecitabine. Other patients received best supportive care only.

\section{Discussion}


De nos jours, le standard de traitement des cancers ORL récurrents ou métastatiques est la combinaison de platine, 5-FU et cetuximab suivie d'un traitement de maintenance par cetuximab. En effet, dans l'étude EXTREME, ${ }^{4}$ l'adjonction de cetuximab au 5 FU et au platine a permis d'obtenir un taux de réponse de 36\%, une augmentation de la PFS de 3,3 à 5,6 mois et de la survie de 7,4 à 10,1 mois. Cependant, la triple association était associée à un risque plus élevé de sepsis grave (9 vs 1 patients, $\mathrm{p}=0,02$ ) et à une toxicité cutanée de grade 3-4 de $9 \%(v s<1 \%, p<0,001)$. Les patients inclus étaient en bon état général (indice de Karnofsky $\geq$ 80 chez plus de $88 \%$ des patients) et n'avaient pas de défaillance d'organes. De ce fait, beaucoup de patients ne sont pas éligibles à ce protocole et d'autres stratégies thérapeutiques doivent donc être envisagées. Il apparaît ainsi 2 groupes de patients. Le premier correspond aux patients en bon état général, en 1ère ligne métastatique ou en rechute locorégionale, pouvant bénéficier du traitement optimal cité ci-dessus. Le 2ème groupe de patients comprend les cas de récidive après traitement à base de platine, les patients en moins bon état général ou présentant des comorbidités rendant impossible la réalisation de cette association de traitement. Pour ceux-là, d'autres options thérapeutique doivent être envisagées.

De nombreuses molécules ont été testées en monothérapie ou en association, comme le méthotrexate, le carboplatine, le docetaxel, le paclitaxel, la capecitabine, le pemetrexed ou le cetuximab, avec des taux de réponse variant entre 10 et $50 \% .^{5,13,14,15,16}$

L'utilisation d'agents en monothérapie peut être utile chez les patients fragiles, dénutris, présentant des comorbidités, des défaillances d'organe ou ayant reçu plusieurs lignes de traitement. Classiquement, le méthotrexate est un agent de 2ème ligne de choix après utilisation des sels de platine du fait de son bon profil de tolérance. Malgré un taux de réponse faible ( 8 à 16\%), il permet d'observer une médiane de survie de l'ordre de 6 mois. ${ }^{5,17}$ Les taxanes utilisés en monothérapie chez les patients réfractaires au platine ont une efficacité modérée avec des taux de réponse de $10 \%$ (docetaxel) à 20\% (paclitaxel). ${ }^{18,19}$ La capecitabine 
permet d'obtenir un taux de réponse de $17 \%$ chez des patients ayant également déjà reçus des platines. $^{20}$

La vinorelbine est un autre agent cytotoxique. Son efficacité en monothérapie a déjà été étudiée dans les cancers ORL récidivants ou métastatiques. En effet, l'étude de Degardin M. et al de l'EORTC-ECSG en 1998 retrouvait un taux de réponse de 16\% chez des patients en situation de rechute ou métastatique non traités précédemment avec une médiane de survie sans progression de 3 mois, une survie médiane de 8 mois et une durée médiane de réponse de 4,7 mois suggérant une activité intéressante de la molécule dans ce type de cancers. ${ }^{9}$

Au vu de ces résultats, il nous a semblé intéressant d'utiliser cette molécule en 2ème ligne ou plus chez des patients présentant une rechute locorégionale ou métastatique.

Notre étude retrouve un taux de réponse nul mais un temps jusqu'à progression du même ordre de 2,6 mois. Bien que la comparaison entre les études soit délicate, on note cependant que la médiane de survie est plus faible dans notre étude (3,4 mois vs 8 mois). Cette différence peut être attribuée au faible nombre de patients inclus ( $\mathrm{n}=23$ ), et au fait que nos patients aient été plus lourdement traités antérieurement (69\% des patients avaient reçus au moins 2 lignes de chimiothérapie avant la vinorelbine et plus de $70 \%$ de nos patients avaient bénéficié d'une chimiothérapie à base de platine alors qu'aucun patient n'avait reçu de chimiothérapie hormis néo-adjuvante ou adjuvante dans l'étude de l'EORTC). Ce traitement était par ailleurs bien toléré et 8 patients (35\%) ont pu recevoir une autre ligne de chimiothérapie après la vinorelbine.

L'efficacité de la vinorelbine apparaît moindre que celle d'autres agents cytotoxiques en monothérapie chez les patients présentant un cancer ORL récidivant ou métastatique. Son usage ne peut donc pas être recommandé dans cette situation. 


\section{References}

1. Torre LA, Bray F, Siegel RL, Ferlay J, Lortet-Tieulent J, Jemal A. Global cancer statistics, 2012. CA Cancer J Clin 2015;65:87-108.

2. Binder-Foucard F, Bossard N, Delafosse P, et al. Cancer incidence and mortality in France over the 1980-2012 period: solid tumors. Rev Epidemiol Sante Publique 2014;62:95108.

3. Pignon JP, le Maitre A, Maillard E, Bourhis J, Group M-NC. Meta-analysis of chemotherapy in head and neck cancer (MACH-NC): an update on 93 randomised trials and 17,346 patients. Radiother Oncol 2009;92:4-14.

4. Vermorken JB, Mesia R, Rivera F, et al. Platinum-based chemotherapy plus cetuximab in head and neck cancer. N Engl J Med 2008;359:1116-27.

5. Forastiere AA, Metch B, Schuller DE, et al. Randomized comparison of cisplatin plus fluorouracil and carboplatin plus fluorouracil versus methotrexate in advanced squamous-cell carcinoma of the head and neck: a Southwest Oncology Group study. J Clin Oncol 1992;10:1245-51.

6. Leon X, Hitt R, Constenla M, et al. A retrospective analysis of the outcome of patients with recurrent and/or metastatic squamous cell carcinoma of the head and neck refractory to a platinum-based chemotherapy. Clin Oncol (R Coll Radiol) 2005;17:418-24.

7. Le Chevalier T. Adjuvant chemotherapy for resectable non-small-cell lung cancer: where is it going? Ann Oncol 2010;21 Suppl 7:vii196-8.

8. Oostendorp LJ, Stalmeier PF, Donders AR, van der Graaf WT, Ottevanger PB. Efficacy and safety of palliative chemotherapy for patients with advanced breast cancer pretreated with anthracyclines and taxanes: a systematic review. Lancet Oncol 2011;12:105361. 
9. Degardin M, Oliveira J, Geoffrois L, et al. An EORTC-ECSG phase II study of vinorelbine in patients with recurrent and/or metastatic squamous cell carcinoma of the head and neck. Ann Oncol 1998;9:1103-7.

10. Kornek V, Scheithauer W, Glaser C, et al. Vinorelbine and carboplatin in recurrent and/or metastatic squamous cell carcinoma of the head and neck. Oncology 1999;56:24-7. 11. Segura A, Pastor M, Santaballa A, Yuste A, Lopez P, Aparicio J. Cisplatin plus vinorelbine for patients with advanced head and neck squamous cell carcinoma. Oncologist 2000;5:177-8.

12. Espinosa E, Zamora P, Milla A, et al. A phase II trial of cisplatin and vinorelbine in patients with recurrent or metastatic squamous cell carcinoma of the head and neck. Head Neck 2002;24:1054-9.

13. Price KA, Cohen EE. Current treatment options for metastatic head and neck cancer. Curr Treat Options Oncol 2012;13:35-46.

14. Ferrari D, Fiore J, Codeca C, et al. A phase II study of carboplatin and paclitaxel for recurrent or metastatic head and neck cancer. Anticancer Drugs 2009;20:185-90.

15. Argiris A, Kotsakis AP, Hoang T, et al. Cetuximab and bevacizumab: preclinical data and phase II trial in recurrent or metastatic squamous cell carcinoma of the head and neck. Ann Oncol 2013;24:220-5.

16. Peron J, Ceruse P, Lavergne E, et al. Paclitaxel and cetuximab combination efficiency after the failure of a platinum-based chemotherapy in recurrent/metastatic head and neck squamous cell carcinoma. Anticancer Drugs 2012;23:996-1001.

17. Schornagel JH, Verweij J, de Mulder PH, et al. Randomized phase III trial of edatrexate versus methotrexate in patients with metastatic and/or recurrent squamous cell carcinoma of the head and neck: a European Organization for Research and Treatment of Cancer Head and Neck Cancer Cooperative Group study. J Clin Oncol 1995;13:1649-55. 
18. Zenda S, Onozawa Y, Boku N, Iida Y, Ebihara M, Onitsuka T. Single-agent docetaxel in patients with platinum-refractory metastatic or recurrent squamous cell carcinoma of the head and neck (SCCHN). Jpn J Clin Oncol 2007;37:477-81.

19. Fayette J, Montella A, Chabaud S, et al. Paclitaxel is effective in relapsed head and neck squamous cell carcinoma: a retrospective study of 66 patients at a single institution. Anticancer Drugs 2010;21:553-8.

20. Peron J, Poupart M, Ceruse P, et al. Efficacy and safety of capecitabine in heavily pretreated recurrent/metastatic head and neck squamous cell carcinoma. Anticancer Drugs 2012;23:1107-11. 
Legends of figures

Figure 1 - Kaplan-Meier estimates of progression free survival for all patients.

Figure 2 - Kaplan-Meier estimates of overall survival for all patients. 
Figure 1.

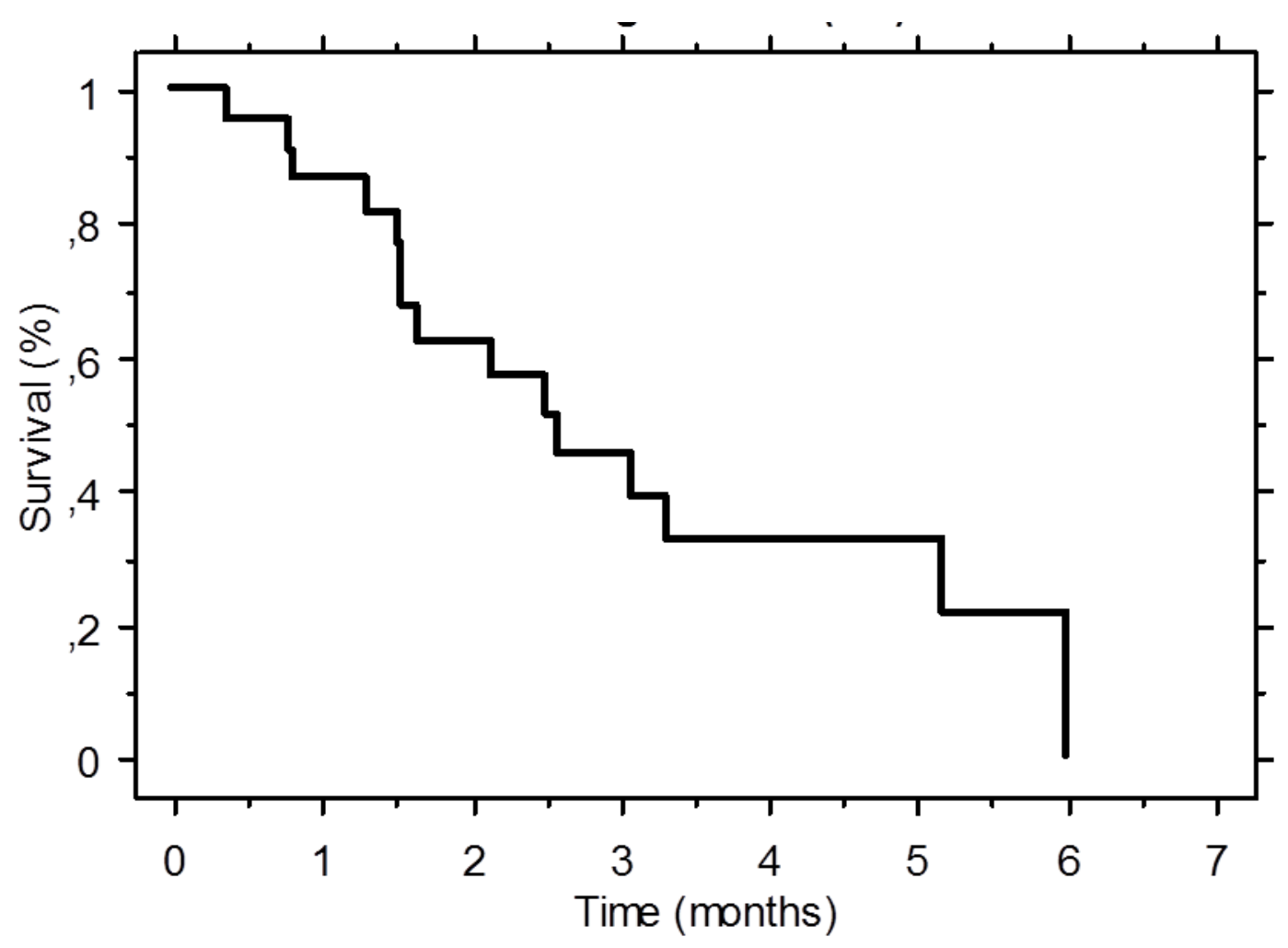


Figure 2.

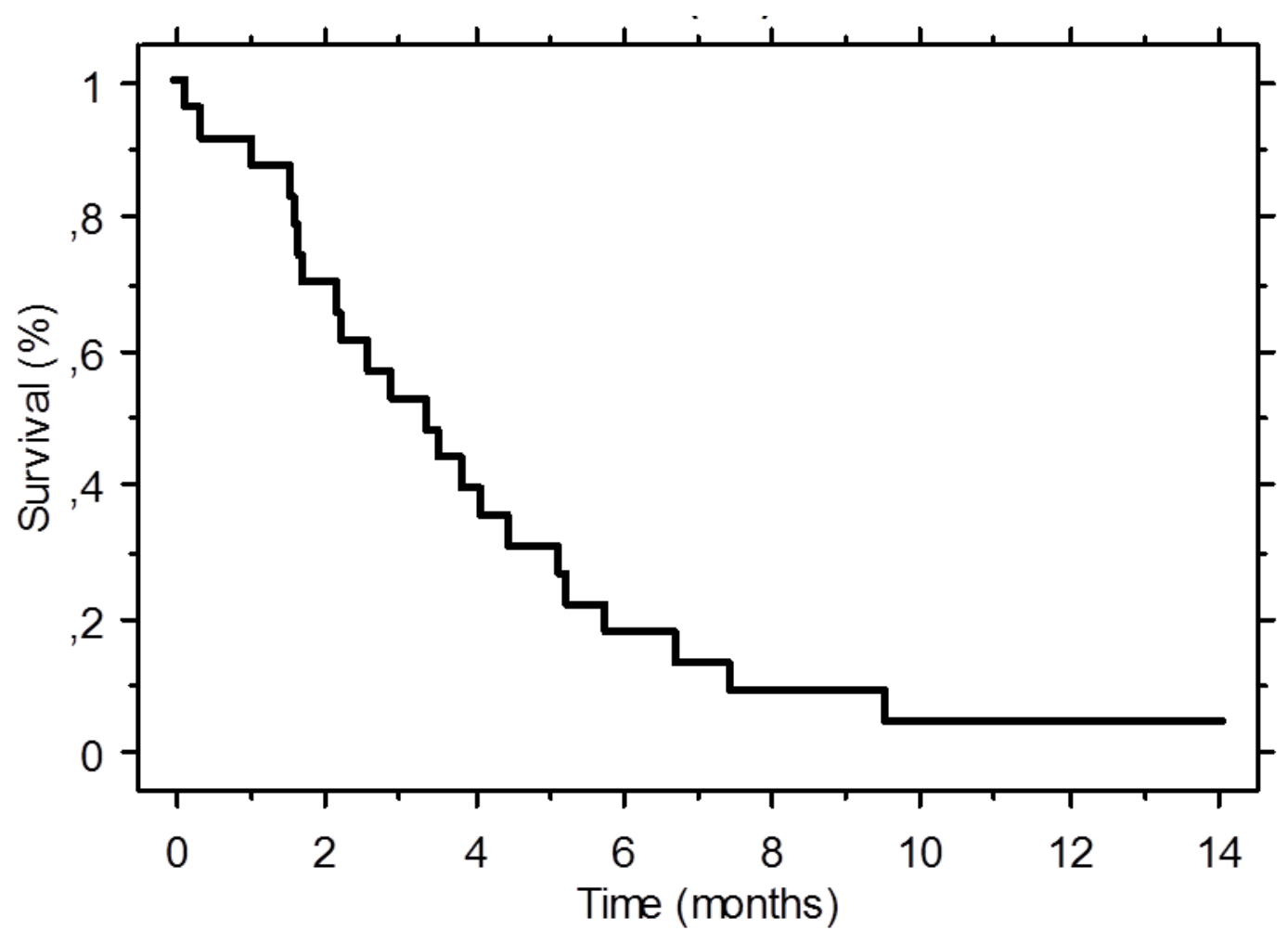




\section{Tables}

Table 1 - Initial characteristics of patients.

\begin{tabular}{|c|c|}
\hline Characteristics & $\begin{array}{l}\text { Total } \\
n=23\end{array}$ \\
\hline \multicolumn{2}{|l|}{ Age (years old) } \\
\hline median & 61 \\
\hline range & $34-83$ \\
\hline \multicolumn{2}{|l|}{$\operatorname{Sex}(n ; \%)$} \\
\hline male & $17(74)$ \\
\hline female & $6(26)$ \\
\hline \multicolumn{2}{|c|}{ Initial T stage (n ; \%) } \\
\hline $\mathrm{T} 1$ & $3(13)$ \\
\hline $\mathrm{T} 2$ & $5(22)$ \\
\hline $\mathrm{T} 3$ & $8(35)$ \\
\hline $\mathrm{T} 4$ & $7(30)$ \\
\hline \multicolumn{2}{|c|}{ Initial N stage $(\mathrm{n} ; \%)$} \\
\hline NO & $6(26)$ \\
\hline N1 & $4(17)$ \\
\hline $\mathrm{N} 2 \mathrm{a}$ & $2(9)$ \\
\hline $\mathrm{N} 2 \mathrm{~b}$ & $2(9)$ \\
\hline $\mathrm{N} 2 \mathrm{c}$ & $3(13)$ \\
\hline N3 & $6(26)$ \\
\hline
\end{tabular}

Tumor location (n;\%)

oral cavity 
oropharynx

$\operatorname{larynx}$

hypopharynx

nasopharynx

Initial treatment $(\mathrm{n} ; \%)$

Surgery

Surgery followed by RT

ICT followed by surgery

ICT followed by surgery and RT

RT

ICT followed by RT
$10(44)$

$3(13)$

$5(22)$

$1(4)$

$2(9)$

$2(9)$

$7(30)$

$3(13)$

$7(30)$

Abbreviations: $\mathrm{n}$, number of patients; $\mathrm{T}$, tumor; $\mathrm{N}$, lymphe node; RT, radiation therapy; ICT, induction chemotherapy. 
Table 2 - Different lines of chemotherapy prior vinorelbine for recurrent or metastatic

HNSCC.

\begin{tabular}{lccc}
\hline Chemotherapy & $\mathbf{1}^{\text {st }}$ line & $\mathbf{2}^{\text {nd }}$ line & $\mathbf{3}^{\text {rd }}$ line \\
& (n) & (n) & (n) \\
\hline Cisplatin & 11 & 4 & 1 \\
Cetuximab & 6 & 10 & 3
\end{tabular}

Abbreviations: $\mathrm{n}$, number of patients 
Table 3 - Toxicity according to the Common Terminology Criteria for Adverse Events (CTCAE) version 4.0.

\begin{tabular}{lcc}
\hline Toxicity & Grade 1-2 & Grade 3-4 \\
\hline Hematological $(\mathrm{n} ; \%)$ & $5(22)$ & 0 \\
Anemia & $2(9)$ & $2(9)$ \\
Neutropenia & 0 & 0 \\
Thrombopenia & $1(4)$ & 0 \\
Gastro-intestinal (n;\%) & $5(22)$ & 0 \\
Nausea - vomiting & $3(13)$ & 0 \\
Diarrhea & & 0 \\
Constipation & $1(4)$ & 0 \\
Other (n ; $)$ & $1(4)$ & $1(4)$ \\
Hepatic cytolysis & $1(4)$ & 0 \\
Mucositis & & \\
Asthenia & & \\
\hline
\end{tabular}

Abbreviations: $\mathrm{n}$, number of patients 